\title{
A CASE OF MULTISYSTEM INFLAMMATORY SYNDROME IN CHILDREN PRESENTING AS ACUTE APPENDICITIS AND PANCREATITIS
}

\author{
Lidija Kareva $^{1}$, Katarina Stavrik ${ }^{1}$, Kristina Mironska ${ }^{1}$, \\ Arjeta Hasani $^{1}$, Sonja Bojadzieva ${ }^{2}$, Natalija Cokleska Shuntov ${ }^{3}$ \\ ${ }^{1}$ Department of Immunology, University Pediatric Clinic, University Ss. Cyril and Methodius, Skopje, N Macedonia \\ ${ }^{2}$ Department of gastroenterohepatology, University Pediatric Clinic, University Ss. Cyril and Methodius, Skopje, N Macedonia \\ ${ }^{3}$ University Pediatric Surgery Clinic, University Ss. Cyril and Methodius, Skopje, N Macedonia
}

Corresponding author: Lidija Kareva M.D. University Pediatric Clinic, Ss. Cyril and Methodius University, Vodnjanska 17, 1000 Skopje Republic of North Macedonia, Phone: +389075215613, Email: kvlidija@yahoo.com

\begin{abstract}
Multisystem Inflammatory Syndrome in Children (MIS-C) is characterized by an inflammation with fever, elevated inflammatory markers, conjunctivitis, rash, impaired coagulation, gastrointestinal symptoms and cardiac abnormalities that may progress to multiorgan failure. The presence of a positive COVID-19 antigen via a PCR test, serological testing for antibodies or close contact with a person diagnosed with COVID-19 helps differentiate MIS-C from other diseases.

Gastrointestinal symptoms are recognized to be associated with COVID-19 infection or MIS-C in children, presenting as abdominal pain, gastrointestinal infection with watery stools, appendicitis, ileitis, pancreatitis and hepatitis, confusing the diagnosis with other gastrointestinal diseases.

In this case report, we describe an 11 year old boy with MIS-C, who presents acute phlegmona of the appendix for which he undergoes appendectomy, accompanied with acute pancreatitis. These manifestations of MIS-C in our patient resolved without additional complications after a 2 month follow up.

We call attention to MIS-C presenting in pediatric patients with fever and abdominal pain which might be caused by appendicitis and pancreatitis, and we recommend abdominal imaging and additional laboratory investigation to promote earlier diagnosis.
\end{abstract}

Keywords: COVID-19, SARS-CoV-2, MIS-C, appendicitis, pancreatitis

\section{BACKGROUND}

The SARS-CoV-2 pandemic, caused by the COVID-19 virus, has had a wide range of clinical manifestations, from asymptomatic cases to severe acute respiratory distress syndrome, and death [1, 2]. Pediatric patients usually have a milder course of the infection than adults [3-6] and they can be asymptomatic carriers of the virus [4]. However, a growing number of reports has now shown a severe inflammatory syndrome in children, simi- lar to Kawasaki disease, a vasculitis of unknown origin discovered in Japan in 1967 [7, 8, 9]. This new syndrome has been named multisystem inflammatory syndrome in children (MIS-C) [10]. MIS-C is characterized by an inflammation with fever, elevated inflammatory markers, conjunctivitis, rash, impaired coagulation, gastrointestinal symptoms, edema and cardiac abnormalities which may progress to multiorgan failure [11-15]. 
There is overlap between MIS-C and Kawasaki disease. The presence of a positive COVID-19 antigen via PCR test, serological testing for antibodies, or close contact with a person diagnosed with COVID-19 help differentiate MIS-C from other diseases. Affected patients with MIS-C may require intensive care and benefit from additional therapies against inflammatory response [16].

Gastrointestinal symptoms are recognized to be associated with a COVID-19 infection or MIS-C in children, presenting as abdominal pain, gastrointestinal infection with watery stools, appendicitis, ileitis, pancreatitis and hepatitis, confusing the diagnosis with other gastrointestinal diseases $[15,17,18]$.

In this case report, we describe a patient who presents MIS-C with acute appendicitis who is undergoing an appendectomy, accompanied with acute pancreatitis. MIS-C and abdominal manifestations are resolved without additional complications after a 2 month follow up.

\section{CASE PRESENTATION}

Our patient is a previously healthy 11 -yearold boy who has visited our clinic due to fever and abdominal pain, which lasted for 4 days before admission. After receiving a negative PCR swab for COVID-19, the child and his mother were admitted to our clinic for further diagnostic procedures and treatment. The patient has a positive epidemiological history of COVID-19 infection. His mother and father had symptoms of a COVID-19 infection with positive PCR test one month before admission and were treated on an outpatient basis. The 11-year-old patient was asymptomatic and was therefore not tested.

Upon admission, the patient had a high fever, watery stools, diffuse abdominal pain, muscle pain of the extremities and a headache. Main symptoms at the admission to the hospital and after the surgery are summarized on (Table 1)

The child appeared conscious, pale, dehydrated with dry tongue and hyperemic tonsillopharyngitis. Upon auscultation of the lungs, the patient's breathing on both sides was basally weakened. Meningeal signs were negative.

Laboratory work (Table 2) was notable for elevated inflammatory markers with a high number of leukocytes in the hemogram with a predominance of neutrophils, anemia, and elevated
C-reactive protein (CRP). COVID-19 from the nasopharyngeal swab was negative while a test for COVID-19 IgG from a serum was positive positive-32.28 AU / $\mathrm{ml}$, and he was formally diagnosed with post-viral MIS-C. Troponin was elevated at $30.5 \mathrm{ng} / \mathrm{1}$, D dimers were elevated. Blood and stool cultures were both negative. A chest X-ray showed bilateral basal pneumonia. Echocardiographic examination showed mitral valve prolapse without pathology on the coronary arteries.

Treatment was started with a parenteral antibiotic therapy, anticoagulant therapy, and parenteral corticosteroids. Vital parameters were measured during the stay and they remained within stable values.

Due to the abdominal pain, an echotomographic examination of the abdomen was performed and free fluid in the pelvis and ileocecal was noted. A CT scan of the abdomen and thorax was performed where we found small pleural effusions with visible linear infiltrations in the distal sections of the lungs, bilaterally (Figure1). The liver, spleen, pancreas, adrenal glands, kidneys and bladder did not show pathological changes. In the ileocecal region, the appendix vermiformis presented moderate edema of the appendix and surrounding adipose tissue was an inflammatory response, as well as markedly enlarged lymph nodes. Free fluid was detected in the small pelvis. The finding was mostly in favor of acute appendicitis (Figure 2).

At 48 hours after admission, our differential diagnoses included atypical $\mathrm{KD}$, and/or COVID-19-related MIS-C with appendicitis. The pediatric surgeon determined that surgical intervention was necessary and the child was transferred to the pediatric surgery clinic.

The child was at the surgery department for 7 days. An appendectomy was performed. The patient's pathohistology showed acute phlegmona of the appendix. The patient had a complicated postoperative course, with fever, abdominal pain, hypoproteinemia, generalized edema, dyspnea, progression of pleural effusion, conjunctivitis, electrolyte imbalances, hypokalemia, hypocalcemia, increased D-dimers, and increased serum lipase and amylase, suggestive for acute pancreatitis.

During the stay at the surgical department he was substituted with plasma and albumin, treated with fluids, underwent antibiotic therapy, corticosteroids, anticoagulants, and received ox- 
Table 1. Symptoms of the disease

\begin{tabular}{|l|c|c|}
\hline Symptoms & Before surgery & After surgery \\
\hline Fever & $5 \mathrm{~d}$ & $6 \mathrm{~d}$ \\
\hline Abdominal pain & + & + \\
\hline Vomitus & - & + \\
\hline Diarrhea & + & - \\
\hline Skin rash & - & - \\
\hline Conjunctivitis & - & + \\
\hline Dyspnea & - & + \\
\hline Edema & - & + \\
\hline Muscle pain & + & + \\
\hline Headache & + & - \\
\hline
\end{tabular}

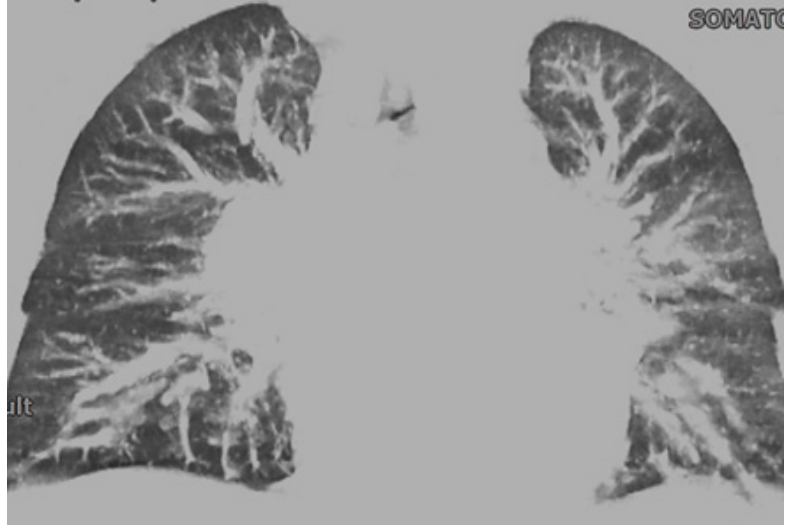

Figure 1. CT of the lungs in a patient with multisystem inflammatory disease related to COVID-19

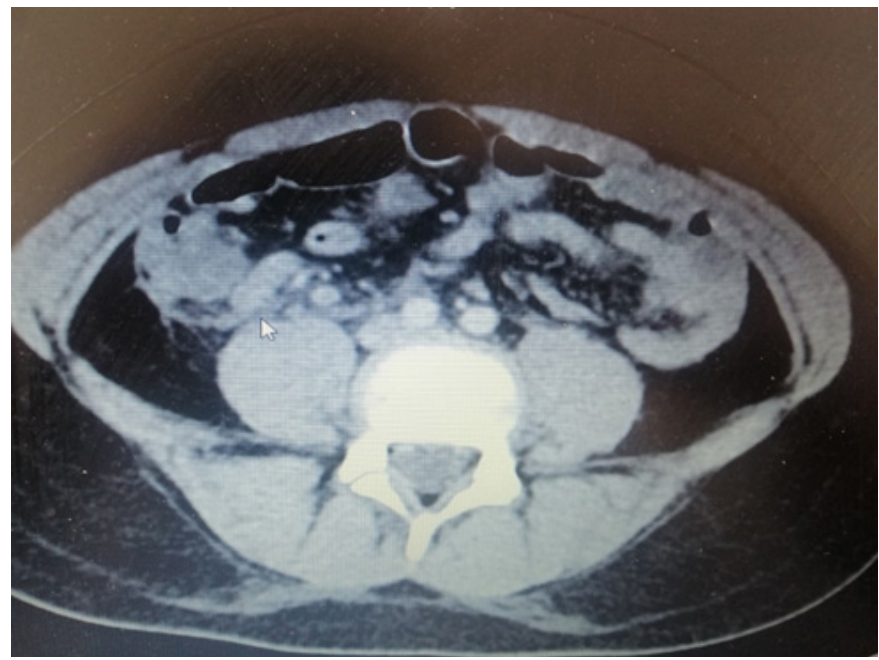

Figure 2. CT of inflamed appendix in a patient with multisystem inflammatory disease related to COVID-19

ygen support. High doses of intravenous immunoglobulin $(1 \mathrm{~g} / \mathrm{kg})$ were given.

After stabilization, the patient was transferred back to the pediatric ward, where antibiotic therapy, corticosteroids, and anticoagulants were continued. Due to the growth of pancreatic enzymes, a diet was prescribed.

Additionally, full-time multidisciplinary examinations were performed by an immunologist, gastroenterohepatologist, cardiologist, and pediatric surgeon. Gradually, the patient's condition has stabilized, within normalized clinical and laboratory parameters.

Echotomographic examination of the abdomen at the time of discharge demonstrated small residual fluid collection in the pelvis. The patient was discharged without any medication and advice for any pending follow-ups with the immunology, cardiology and gastroenterology departments. At the 2 month follow-up he had normal clinical and laboratory findings.

\section{DISCUSSION}

MIS-C associated with COVID-19 infection is thought to occur secondary to a cytokine storm that damages numerous organ systems. The inflammatory response results in dilation of the blood vessels, leading to hypotension, fluid accumulation, and shock. As we expand our understanding of MIS-C secondary to COVID-19, we recognize that there is likely a broader spectrum of signs and symptoms.

There are numerous reports of abdominal pain in children with COVID-19 infection and/or MIS-C. In a single center study (19) in the UK, authors present 8 children with COVID-19 and 
Table 2. Laboratory parameters

\begin{tabular}{|c|c|c|c|c|}
\hline Parameter & Upon admission & After surgery & Upon discharge & Reference range \\
\hline Hemoglobin & 109 & 98 & 147 & $\mathrm{~g} / \mathrm{l}$ \\
\hline Erythrocytes & 3,71 & 3.22 & 4.66 & $3.50-5.20 \times 10^{6} / \mathrm{uL}$ \\
\hline Hematocrit & 30,3 & 26,2 & 40,6 & $34.1-45.0 \%$ \\
\hline Leucocytes & 19,3 & 13,3 & 6,1 & $3,50-10.00 \times 10^{3} / \mathrm{uL}$ \\
\hline Neutrophils & 18,0 & 10,1 & 3,60 & $1.50-6.20 \times 10^{3} / \mathrm{uL}$ \\
\hline Lymphocytes & 0.66 & 2.3 & 2.22 & $1.20-3.74 \times 10^{3} / \mathrm{uL}$ \\
\hline Monocytes & 0.40 & & 0.13 & $0.20-0.80 \times 10^{3} / \mathrm{uL}$ \\
\hline Eosinophils & 0.00 & & 0.04 & $0.04-0.45 \times 10^{3} / \mathrm{uL}$ \\
\hline Platelets & 168 & 329 & 267 & $150-400 \times 10^{3} / \mathrm{uL}$ \\
\hline Urinalysis & normal & normal & & normal \\
\hline Serum iron & 2.9 & & 12,5 & $6.6-26.0 \mathrm{umol} / \mathrm{L}$ \\
\hline Ferritin & 450.3 & & 168,3 & $30.0-400 \mathrm{ug} / \mathrm{L}$ \\
\hline Transferrin & 206.2 & & 172,19 & $130.0-360.0 \mathrm{mg} / \mathrm{dL}$ \\
\hline Urea & 3,1 & 3,0 & 3,1 & $2.6-6.4 \mathrm{mmol} / 1$ \\
\hline Creatinine & 56 & 53 & 57 & 0-104 umol/L \\
\hline Troponin & 30.5 & & 18 & $<19 \mathrm{ng} / \mathrm{ml}$ \\
\hline Serum protein & 65 & 59 & 77 & $64-83 \mathrm{~g} / \mathrm{L}$ \\
\hline Serum albumin & 38 & 34 & 42 & $40-49 \mathrm{~g} / \mathrm{L}$ \\
\hline Serum bilirubin & 14,7 & 6,0 & 8,1 & $22 \mathrm{umol} / 1$ \\
\hline AST & 60 & 23 & 24 & $15-59 \mathrm{U} / \mathrm{L}$ \\
\hline ALT & 67 & 34 & 30 & 9-72 U/L \\
\hline GGT & 78 & & 34 & $0-36 \mathrm{U} / \mathrm{L}$ \\
\hline $\mathrm{LDH}$ & 327 & & 274 & $0-500 \mathrm{U} / \mathrm{L}$ \\
\hline CRP & 216,3 & 13 & 0,8 & $0.00-5.0 \mathrm{mg} / \mathrm{L}$ \\
\hline D dimers & 2940 & 8400 & 160,3 & $0-500 \mathrm{ngr} / \mathrm{ml}$ \\
\hline Glycaemia & 8,5 & 5,56 & 5,49 & $4.10-5.90 \mathrm{mmol} / 1$ \\
\hline Sodium & 139 & 139 & 138 & $136-145 \mathrm{mmol} / \mathrm{l}$ \\
\hline Potassium & 4,2 & 3,2 & 4,4 & $3.5-5.1 \mathrm{mmol} / 1$ \\
\hline Calcium & 2,13 & 2,09 & 2,49 & $2.1-2.55 \mathrm{mmol} / 1$ \\
\hline $\begin{array}{l}\text { Amylase } \\
\text { (serum) }\end{array}$ & & 489 & 102 & $25-125 \mathrm{U} / \mathrm{L}$ \\
\hline Lipase (serum) & & 576 & 66 & 8-78 U/L \\
\hline IL6 & & 141 & 8,66 & $<7.00 \mathrm{pg} / \mathrm{ml}$ \\
\hline
\end{tabular}

symptoms of atypical appendicitis. All children had imaging confirming terminal ileitis and no surgical intervention was required. Four of the children were treated with intravenous immunoglobulins for atypical Kawasaki disease. A case report [20] of a girl with MIS-C and abdominal pain undergoing surgical procedure for appendectomy, with findings of appendicitis and ileitis. This was treated with resection of the appendix and a section of the small intestine and contributed to the previous series of studies. In a series of 4 children [21], from 5 to 12 years of age, with appendicitis and confirmed COVID-19 infection upon a PCR test, three were initially diagnosed with acute appendicitis and treated surgically and multisystem inflammatory syndrome in children (MIS-C) was diagnosed in all three after appendectomies. The fourth child was admitted with clinical appendicitis and tested positive for COVID-19 but was managed non-surgically and did not have MIS-C.

Our patient initially presented fever, diffuse abdominal pain, watery stools, headache and muscle pains. He had positive antibodies for COVID-19, suggestive for MIS-C. Imaging studies helped diagnose appendicitis. The patient had undergone an appendectomy with histological findings of empyema of the appendix without terminal ileum involvement. The patient's surgery wound healed without complications. 
Rapid deterioration after surgery in our patient prompted additional investigation and the presence of acute pancreatitis was noted, having elevated serum lipase and amylase. The two of these, together with persistent abdominal pain in upper abdomen, were the basis of our diagnosis. However, echotomographic examination as well as a CT scan of the abdomen upon admission did not show any visual changes in pancreatic tissue, suggesting that pancreatitis has fully developed later during the course of the disease.

There are several reports of acute pancreatitis and COVID-19 infection. In a retrospective study of pediatric patients admitted to a large health system in New York [22], for a 3 month period during the COVID-19 pandemic in 2020, out of 8159 pediatric patients, 112 were diagnosed with COVID-19. Thirteen were diagnosed with pancreatitis. Of the thirteen patients admitted with pancreatitis, two patients tested positive for COVID-19, for a point prevalence of $1.8 \%$ among COVID-19 patients compared to $0.14 \%$ in the non-COVID-19 population. This study shows that pancreatitis can occur in pediatric patients with the COVID-19 infection. Other studies noted the occurrence of pancreatitis in acute COVID-19 infection in children [23], as well as in patients with MIS-C as part of clinical presentation [24, 25].

The mechanism for the development of such diseases in this population is unclear, perhaps due to a direct cytopathic effect from the COVID-19 virus, or as a result of the ischemic and systemic inflammatory states that can occur with MIS-C.

In summary, appendicitis and pancreatitis can occur in pediatric patients with COVID-19 and MIS-C. Our case is unique in that we found an MIS-C patient who had both appendicitis and acute pancreatitis as manifestations of the disease. In reviewing this clinical case, our hospital developed and implemented a new screening protocol for MIS-C patients with abdominal pain, which might be caused by appendicitis and pancreatitis, and we recommend abdominal imaging and additional laboratory investigations to promote an earlier diagnosis.

\section{REFERENCES}

1. Guan W-J, Ni Z-Y, Hu Y, et al:Clinical characteristics of coronavirus disease 2019 in China. N Engl J Med 2020;382:1708-20.doi:10.1056/
NEJMoa2002032pmid:http://www.ncbi.nlm.nih. gov/pubmed/32109013

2. Zhou F, Yu T, Du R, et al:Clinical course and risk factors for mortality of adult inpatients with COVID-19inWuhan, China: aretrospectivecohort study. Lancet 2020;395:1054-62.doi:10.1016/ S0140-6736(20)30566-3pmid:http://www.ncbi. nlm.nih.gov/pubmed/32171076

3. Castagnoli R, Votto M, Licari A, et alSevere acute respiratory syndrome coronavirus 2 (SARSCoV-2) infection in children and adolescents: a systematic review. JAMA Pediatr 2020. doi:doi:10.1001/jamapediatrics.2020.1467. [Epub ahead of print: 22 Apr 2020].pmid:http://www. ncbi.nlm.nih.gov/pubmed/32320004

4. Mehta NS, Mytton OT, Mullins EWS, et alSARS-CoV-2 (COVID-19): what do we know about children? A systematic review. Clin Infect Dis 2020.doi:10.1093/cid/ciaa556

5. Sankar J, Dhochak N, Kabra SK, et al. COVID-19 in children: clinical approach and management. Indian J Pediatr 2020;87:433-42.doi:10.1007/ s12098-020-03292-1pmid:http://www.ncbi.nlm. nih.gov/pubmed/32338347

6. Zimmermann P, Curtis N.COVID-19 in children, pregnancy and neonates: a review of epidemiologic and clinical features. Pediatr Infect Dis J 2020;39:469-77.doi:10.1097/ INF.0000000000002700pmid:http://www.ncbi. nlm.nih.gov/pubmed/32398569

7. Kawasaki T. Acute febrile mucocutaneous syndrome with lymphoid involvement with specific desquamation of the fingers and toes in children. Japanese J Allergol. 1967;16:178.

8. Riphagen S, Gomez X, Gonzalez-Martinez C, Wilkinson N, Theocharis P. Hyperinflammatory shock in children during COVID-19 pandemic. Lancet. 2020;395:1607.

9. Verdoni L, Mazza A, Gervasoni A, Martelli L, Ruggeri M, Ciuffreda M, et al. An outbreak of severe Kawasaki-like disease at the Italian epicentre of the SARS-CoV-2 epidemic: an observational cohort study. Lancet. 2020;395:1771.

10. Center for Disease Control and Prevention, US Department of Health \& Human Services Multisystem inflammatory syndrome in children (MIS-C) associated with coronavirus disease 2019 (COVID-19), 2020. Available: https:// emergency.cdc.gov/han/2020/han00432.asp

11. Freedman SG-C S, Gorman R, Lodha R, et al Multisystem inflammatory syndrome in children and adolescents temporally related to COVID-19, 2020. Available: https://www.who.int/news$\mathrm{room} / \mathrm{commentaries/detail/multisystem-in-}$ flammatory-syndrome-in-children-and-adolescents-with-covid-19

12. Mahase E Covid-19: cases of inflammatory syndrome in children surge after urgental- 
ert. BMJ 2020;369:m1990. doi:10.1136/bmj. m1990pmid:http://www.ncbi.nlm.nih.gov/ pubmed/32414749

13. Mahase E. Covid-19: concerns grow over inflammatory syndrome emerging in children. BMJ 2020;369:m1710. doi:10.1136/bmj. m1710pmid:http://www.ncbi.nlm.nih.gov/ pubmed/32345602

14. Cheung E. NYC experience with COVID-19: from ICU adaptations to multi-system inflammatory syndrome in children New York Presbyterian/ Columbia University Children's Medicine; 2020.

15. Mubbasheer Ahmeda, Shailesh Advanib,c, 1 , Axel Moreiraa, Sarah Zoreticd, John Martinezd, Kevin Chorathe, Sebastian Acostaa, Rija Naqvia,b,c,d,e , Finn Burmeister-Mortond , Fiona Burmeisterd, Aina Tarrielad, Matthew Petershackd, Mary Evansd, Ansel Hoangd, Karthik Rajasekarane , Sunil Ahujad, Alvaro Moreirad, Multisystem inflammatory syndrome in children: A systematic review *EClinicalMedicine26(2020)100527

16. Royal College of Paediatrics and Child Health. Health RCoPaC. Guidance - Paediatric multisystem inflammatory syndrome temporally associated with COVID-19, 2020. Available: https:// www.rcpch.ac.uk/resources/guidance-paediatric-multisystem-inflammatory-syndrome-temporally-associated-covid-19

17. 110. Jonathan Miller, Amanda Cantor, Philip Zachariah, Danielle Ahn, Mercedes Martinez, and Kara Gross Margolis .Gastrointestinal Symptoms as a Major Presentation Component of a Novel Multisystem Inflammatory Syndrome in Children That Is Related to Coronavirus Disease 2019: A Single Center Experience of 44 Cases Gastroenterology 2020;159:1571-1574

18. Neha Mahajan,Huan Ting Chang, Rachel Leeman, Rachel Manalo and Wendy Robin Glaberson.Case of multisystem inflammatory syndrome in children presenting as fever and abdominal pain.BMJ Case Reports, Volume13,Issue 9,2020
19. Lucinda Tullie, Kathryn Ford,May Bisharat,Tom Watson,Hemanshoo Thakkar,Dhanya Mullassery, Stefano Giuliani, Simon Blackburn,Kate Cross,aPaolo De Coppi, and Joe Curry Gastrointestinal features in children with COVID-19: an observation of varied presentation in eight children. Lancet Child Adolesc Health. 2020 Jul; 4(7): e19-e20.

20. Ramon J Jackson,1 Hector D Chavarria,1 and Sean M HackingA Case of Multisystem Inflammatory Syndrome in Children Mimicking Acute Appendicitis in a COVID-19 Pandemic Area. Cureus. 2020 Sep; 12(9): e10722.Published online 2020 Sep 29. doi: 10.7759/cureus. 10722

21. Lishman, Juanita FCPaed; Kohler, Charles MBChB, MRCS; de Vos, Corne FCPaedSurg; van der Zalm, Marieke M. PhD; Itana, Justina MBChB; Redfern, Andrew FCPaed; Smit, Liezl FCPaed; Rabie, Helena PhD.Acute Appendicitis in Multisystem Inflammatory Syndrome in Children With COVID-19.The Pediatric Infectious Disease Journal: December 2020 - Volume 39 Issue 12 - p e472-e473

22. Kelly Suchman a, Kara L. Raphael b , Yan Liu c, Diana Wee a, Arvind J. Trindade b, c Acute pancreatitis in children hospitalized with COVID-19. Pancreatology 21(2021), 31-33

23. Alloway BC, Yaeger SK, Mazzaccaro RJ, Villalobos T, Hardy SG. Suspected case of COVID-19 associated pancreatitis in a child. Radiology Case Reports 2020;15(8): 1309e12.

24. Stevens JP, Brownell JN, Freeman AJ, Bashaw H. COVID-19-associated multisystem inflammatory syndrome in children presenting as acute pancreatitis. J Pediatr Gastroenterol Nutr DOI: 10.1097/mpg.0000000000002860.

25. Nagehan Aslan, Dincer Yildizdas, Muhammed Selcuk Sinanoglu. A Pediatric COVID19 Case with Suspected Acute Abdomen, Hyperferritinemic Sepsis and Developing MIS-C and Pancreatitis .The Indian Journal of Pediatrics (March 2021) $88(3): 288$ 


\title{
Резиме
}

\section{ПРИКАЗ НА СЛУЧАЈ НА ПАЦИЕНТ СО МУЛТИСИСТЕМСКА ИНФЛАМАТОРНА БОЛЕСТ КАЈ ДЕЦА СО АКУТЕН АПЕНДИЦИТИС И ПАНКРЕАТИТИС}

\author{
Лидија Карева ${ }^{1}$, Катарина Ставриќ ${ }^{1}$, Кристина Миронска ${ }^{1}$, \\ Арјета Хасани ${ }^{1}$, Соња Бојашиева ${ }^{2}$, Наталија Чоклеска Шунтов ${ }^{3}$
}

${ }^{1}$ Оддел за имунологија, Универзитетска детска клиника, Универзитет „Св. Кирил и Методиј“, Скопје, РС Македонија

${ }^{2}$ Оддел за гастроентерохепатологија, Универзитетска детска клиника, Универзитет „Св. Кирил и Методиј“, Скопје, РС Македонија

3 Универзитетска клиника за детска хирургија, Универзитет „Св. Кирил и Методиј“, Скопје, РС Македонија

Мултисистемската инфламаторна болест кај децата (МИС-Ц) се карактеризира со покачена температура, покачени воспалителни маркери, кожен осип, конјунктивитис, нарушувања во коагулацијата на крвта, гастроинтестинални симптоми, како и срцеви засегања што можат брзо да прогредираат кон откажување на повеќе органски ситеми. МИС-Ц е секогаш поврзана со позитивен брис, позитивна серологија или позитивна епидемиолошка анамеза за вирусот КОВИД-19.

Гастроинтестиналните симптоми сѐ повеќе се поврзуваат со акутната инфекција со КОВИД -19 или со МИС-Ц, и се презентираат со стомачна болка, течни столици, апедицитис, илеитис или панкреатитис, а во некои случаи се забележани и хепатални засегања, што понекогаш доведува до тешкотии во дијагнозата.

Нашиот приказ на случај е дете на 11-годишна возраст со МИС-Ц, кај кое е дијагностициран акутен флегмонозен апендицит, за кој беше направена апендектомија, со истовремена појава на панкреатит. Болеста кај нашиот пациент е успешно излекувана, без натамошни здравствени проблеми во текот на следењето во наредните два месеци.

Со овој труд обрнуваме внимание на можноста за појава на апендицитис и панкреатитис кај деца со МИС-Ц, и препорачуваме комплетна лабораториска и имиџинг обработка кај пациенти што се презентираат со стомачна болка, со цел побрзо да се дојде до прецизна дијагноза.

Клучни зборови: КОВИД-19, САРС-КоВ-2, МИС-Ц, апендицитис, панкреатитис 